\title{
ENVIRONMENTAL IMPACT ASSESSMENT OF 17 CONSTRUCTION PROJECTS IN VARIOUS UNIVERSITY CAMPUSES
}

\author{
JOSE C. MORA-BARRANTES, JOSE P. SIBAJA-BRENES, \\ GILBERTO PIEDRA-MARIN \& OSCAR M. MOLINA-LEON \\ School of Chemistry, Universidad Nacional, Costa Rica
}

\begin{abstract}
Environmental impact assessment (EIA) is the process of evaluating the environmental consequences of a plan, policy, programme or any other project prior to the execution of the proposed action; it is the primary instrument for development planning and decision-making. Pollution sources from the construction process include harmful gases, noise, and dust, solid and liquid waste. A large variety of tools is available for environmental assessment of buildings. In Costa Rica, the EIA system is funded on the Costa Rican Political Constitution, the Environmental Organic Law and the General Regulation for the EIA Procedures of 2004. Costa Rica employs an environmental toolkit (environmental assessment form to assign the environmental impact of a new construction project. The toolkit provides a methodology, associated with environmental aspects (EAs), assessment indicators and weighting factors (WF) for each EA. A total of seven impact categories related to natural resources, soil, wildlife, flora and fauna, air, human health, water and socio-cultural are used to establish the WF. The main aim of this research was to evaluate the environmental impact of 17 construction projects to be developed in various university campuses, by using the Costa Rican toolkit. Significant environmental aspects (SEA) were determined in order to evaluate their relationship with the final value of the total environmental impact $\left(\mathrm{TEI}_{\mathrm{p}}\right)$ of each project. The results show that the $\mathrm{TEI}_{\mathrm{p}}$ for the 17 projects evaluated fall in the Low Environmental Impact category. The projects with the higher values of TEI ${ }_{p}$ are those containing internal areas to handle and work with chemical and biological substances, as well as radioactive materials. From the total of the 33 EA evaluated, a 22 of them were classified as SEA. The most common SEA for the projects evaluated are treatment and disposal of ordinary wastes, treatment and disposal of debris building, emissions from mobile sources, production of noise and vibration, population density and employment generation.

Keywords: building, construction, Costa Rica, environmental aspect, environmental indicators, impact assessment, university, weighting factor, waste
\end{abstract}

\section{INTRODUCTION}

The evaluation of the environmental consequences of a plan, policy, programme or any other project prior to the execution of the proposed action is called environmental impact assessment (EIA), and it is considered the primary instrument for development planning and decision-making, as it can serve as a crucial action-forcing mechanism for sustainable development [1]. EIA refers to the anticipation of various impacts that a project will have on the environment and the local community [2] and, as such, aims to ensure the environmental impacts foreseen by decision-makers are taken into account during project development. The EIA has become a powerful tool used to identify the environmental, social and economic impacts of a project prior to decision-making [1]. Selvakumar and Jeykumar [2] point out that EIA "is a formal study process used to predict the environmental consequences of any development project. It is a technique which is meant to help us understand the potential environmental impacts of major development proposals". EIA can be considered as the appraisal of the probable impact that a proposed project may have on the natural environment $[3,4]$. The environmental impact is classified in the following categories: visual impact; material 
impact and resources use; energy impact; space condition and lighting impact; and land use and ecological impact [5, 6]. An EIA requires identifying, describing and assessing the direct and indirect effects that a given project may have on human beings, fauna and flora, soil, water, air, climate and landscape, as well as on socio-economic issues, health and safety in the workplace, material assets and cultural heritage. The interaction among these factors must also be evaluated [7-10].

An environmental aspect (EA) of a particular project is defined as an element of an organization's activities, products or services that can interact with the environment (ISO 14040) [11-13]. These EA are waste generation, energy consumption, water consumption, fossil fuel consumption, land modification, employment generation, people allocation, heritage affectation, landscape modification, raw material consumption, noise and vibration, odour generation, air emissions and so on [14]. Such EA are very common during building construction and operation [14-17]. Compared to other industries, construction industry is a major source of environmental pollution [17], since it has massive direct and indirect effects on the environment [18]. Pollution sources from the construction process include harmful gases, noise, dust, and solid and liquid waste [19]. This pollution issue has encouraged many construction participants to attempt to control the impacts of their activities by adopting environmental management systems [20]. Furthermore, it is expected that foreseeing the ecological impacts of every single building project before the construction stage should lead to improvements in the environmental performance of such projects, as well as of the sites that will be built. The identification of the major environmental impacts will assist in choosing the appropriate on-site mitigation measures [15]; the environmental impacts associated with construction processes include ecosystems, natural resources and public impacts [16].

Improving the environmental performance of buildings requires, for instance, knowledge about environmental impacts of buildings, targets to address, access to building analysis and assessment tools, access to data concerning environmental profiles of products, time, economic resources, goodwill of all parties involved and a structure in building-related decisionmaking processes that enables the inclusion of EA in the design and management processes of buildings and real estate [13,21,22]. A wide variety of tools is available for environmental assessment of buildings; some of them focus on filling out simple checklists, whereas other approaches quantify the environmental impacts associated with building construction, taking into account the entire building life cycle. Both building and realty guilds involve a large number of different actors, with diverse personal interests as well as differences in occupational and educational backgrounds. All these actors may, or rather should, consider EA within their usual decision-making $[13,21]$.

The majority of Latin American countries have acknowledged formal EIA systems for assessing construction projects; as a general rule, the responsibility of supervising the EIA process lies on environmental agencies. Public consultation during the scoping process provides a valuable opportunity to ensure that the EIA includes the impacts of greater concern for all stakeholders. In Latin America, project developers are the ones responsible for hiring the EIA preparers. The official national authority evaluates the EIA prepared by the developer and determines whether or not the assessment meets all legal requirements [23].

The EIA procedures in Costa Rica are centralized at the Environmental National Technical Secretariat (SETENA), a branch of the Environment, Energy and Telecommunications Ministry (MINAET). The main goal of SETENA is to harmonize the environmental impacts of all productive processes carried out in Costa Rica [24, 25]. SETENA employs an electronic assessment outline, called the D-1 form, to preliminarily estimate the potential environmental impact of the new construction projects. The D- 1 form evaluates the direct impact that 
a given project may have on, for instance, the natural resources, social-economic circumstances and human environment, during the construction and operation stages. The major purpose of this electronic outline is to serve as a technical evaluation instrument during the first stages of the EIA, so that SETENA may decide whether or not a planned activity, work or project is feasible from an environmental point of view, as well as to determine if an additional analysis, with a more detailed environmental assessment tool, would be required [25].

Universidad Nacional of Costa Rica (UNA) is a public university founded in 1973 in the city of Heredia; it started operations with a limited budget, modest facilities and a small student population. Over the years, the student body increased significantly, and therefore the initial buildings were not longer satisfactory. In addition, five new campus were created to embrace students from countryside. As a result, newer and better facilities were needed in order to face the new challenges that this growing process brought up. Universidad Nacional started planning 17 new construction projects to be developed during years 2015-2018, in various campus. In order to estimate the potential environmental impact of these new buildings an Environmental Impact Assessment (EIA) was required. The main aim of this work is to apply the SETENA D-1 form to estimate the potential environmental impact of these 17 construction projects. Significant environmental aspects (SEA) were assessed beforehand in order to establish their relationship with the total environmental impact $\left(\mathrm{TEI}_{\mathrm{p}}\right)$ of each project.

\section{METHODOLOGY}

\subsection{SETENA D-1 Form}

In order to determine the TEI of the building projects, the SETENA D-1 form was employed. Such a tool includes several items associated with EA, assessment criteria (AC) and weighting factors (WF). With the intention of establishing the WF, seven impact categories (IC) were established, namely natural resources, soil, flora and fauna, air, human health, water and sociocultural. Table 1 shows the evaluation parameters that are included in the SETENA D-1 form.

Table 1: Parameters included in the SETENA D-1 form for assessing the environmental impacts of construction projects.

\begin{tabular}{|c|c|c|c|c|}
\hline $\begin{array}{l}\text { Impact } \\
\text { category } \\
\text { (IC) }\end{array}$ & $\begin{array}{l}\text { Environmental aspect } \\
\text { (EA) }\end{array}$ & Assessment criteria (AC) & $\begin{array}{l}\text { Numerical } \\
\text { scale }\end{array}$ & $\begin{array}{l}\text { Weighting } \\
\text { factor } \\
(\mathrm{WF})\end{array}$ \\
\hline \multirow{10}{*}{$\begin{array}{l}\text { Natural } \\
\text { resources }\end{array}$} & \multirow{3}{*}{$\begin{array}{l}\text { Water consumption } \\
\text { (WC) }\end{array}$} & \multirow{3}{*}{$\begin{array}{l}\text { Less than } 50 \mathrm{~m}^{3} / \text { month } \\
50-200 \mathrm{~m}^{3} / \text { month } \\
\text { Over } 200 \mathrm{~m}^{3} / \text { month }\end{array}$} & 1 & \multirow[t]{3}{*}{3} \\
\hline & & & 3 & \\
\hline & & & 5 & \\
\hline & \multirow{3}{*}{$\begin{array}{l}\text { Energy consumption } \\
\text { (EC) }\end{array}$} & \multirow{3}{*}{$\begin{array}{l}\text { Less than } 240 \mathrm{Mwh} / \text { year } \\
240-1,200 \mathrm{Mwh} / \text { year } \\
\text { Over 1,200 Mwh/year }\end{array}$} & 1 & \multirow[t]{3}{*}{3} \\
\hline & & & 3 & \\
\hline & & & 5 & \\
\hline & \multirow[t]{4}{*}{ Fossil fuel usage (FF) } & \multirow{4}{*}{$\begin{array}{l}\text { Less than } 5,000.00 \mathrm{~L} \\
5,000.00-50,000.00 \mathrm{~L} \\
50,000.00-500,000.00 \mathrm{~L} \\
\text { Over } 500,000.00 \mathrm{~L}\end{array}$} & 1 & \multirow[t]{4}{*}{4} \\
\hline & & & 2 & \\
\hline & & & 3 & \\
\hline & & & 4 & \\
\hline
\end{tabular}


Table 1: Continued

\begin{tabular}{|c|c|c|c|c|}
\hline $\begin{array}{l}\text { Impact } \\
\text { category } \\
\text { (IC) }\end{array}$ & $\begin{array}{l}\text { Environmental aspect } \\
\text { (EA) }\end{array}$ & Assessment criteria (AC) & Value & $\begin{array}{l}\text { Weighting } \\
\text { factor } \\
\text { (WF) }\end{array}$ \\
\hline \multirow{11}{*}{ Soil } & \multirow{4}{*}{$\begin{array}{l}\text { Soil modification } \\
(\mathrm{SMd})\end{array}$} & No soil modification (1) & 1 & \\
\hline & & Soil modification (5) & 5 & 3 \\
\hline & & $\begin{array}{l}\text { Less than } 10 \% \text { respect } \\
\text { to the drainage area }\end{array}$ & 1 & 2 \\
\hline & & $\begin{array}{l}10-25 \% \text { respect } \\
\text { to the drainage area }\end{array}$ & 2 & \\
\hline & \multirow[t]{3}{*}{$\begin{array}{l}\text { Surface runoff }(\mathrm{SR}) \\
\text { increase }\end{array}$} & $\begin{array}{l}25-50 \% \text { respect } \\
\text { to the drainage area }\end{array}$ & 3 & \\
\hline & & $\begin{array}{l}50-75 \% \text { respect } \\
\text { to the drainage area }\end{array}$ & 4 & \\
\hline & & $\begin{array}{l}\text { Over } 75 \% \text { respect } \\
\text { to the drainage area }\end{array}$ & 5 & \\
\hline & \multirow{4}{*}{$\begin{array}{l}\text { Treatment } \\
\text { and disposal } \\
\text { of ordinary } \\
\text { waste }(\mathrm{OW})\end{array}$} & $\begin{array}{l}\text { Wastes are previously } \\
\text { classified, recovered } \\
\text { and reused before its final } \\
\text { deposition in an own landfill }\end{array}$ & 2 & \multirow[t]{4}{*}{3} \\
\hline & & $\begin{array}{l}\text { Wastes are previously } \\
\text { classified, recovered and reused } \\
\text { before its final deposition in an } \\
\text { external landfill }\end{array}$ & 3 & \\
\hline & & $\begin{array}{l}\text { Wastes are previously classified } \\
\text { before its final deposition in an } \\
\text { external landfill }\end{array}$ & 4 & \\
\hline & & $\begin{array}{l}\text { Wastes are disposed in } \\
\text { an external landfill }\end{array}$ & 5 & \\
\hline & \multirow{4}{*}{$\begin{array}{l}\text { Treatment } \\
\text { and disposal } \\
\text { of special waste }(\mathrm{SW})\end{array}$} & $\begin{array}{l}\text { Wastes are previously } \\
\text { classified, recovered and } \\
\text { reused before its final } \\
\text { deposition in an own landfill }\end{array}$ & 2 & \multirow[t]{4}{*}{3} \\
\hline & & $\begin{array}{l}\text { Wastes are previously } \\
\text { classified, recovered and reused } \\
\text { before its final deposition in an } \\
\text { external landfill }\end{array}$ & 3 & \\
\hline & & $\begin{array}{l}\text { Wastes are previously classified } \\
\text { before its final deposition in an } \\
\text { external landfill }\end{array}$ & 4 & \\
\hline & & $\begin{array}{l}\text { Wastes are disposed in an } \\
\text { external landfill }\end{array}$ & 5 & \\
\hline
\end{tabular}




\begin{tabular}{|c|c|c|c|}
\hline \multirow{2}{*}{$\begin{array}{l}\text { Treatment } \\
\text { and disposal of debris } \\
\text { building (DB) }\end{array}$} & $\begin{array}{l}\text { Wastes are disposed in an own } \\
\text { sanitary landfill or in a private } \\
\text { area (according to the law) }\end{array}$ & 2 & \multirow[t]{2}{*}{3} \\
\hline & $\begin{array}{l}\text { Wastes are disposed in } \\
\text { an external sanitary landfill }\end{array}$ & 4 & \\
\hline \multirow{4}{*}{$\begin{array}{l}\text { Treatment and } \\
\text { disposal of chemical } \\
\text { waste }(\mathrm{CW})\end{array}$} & $\begin{array}{l}\text { Wastes are previously } \\
\text { classified, recovered } \\
\text { and reused before its final } \\
\text { deposition in an own landfill }\end{array}$ & 2 & \multirow[t]{4}{*}{3} \\
\hline & $\begin{array}{l}\text { Wastes are previously } \\
\text { classified, recovered and reused } \\
\text { before its final deposition in an } \\
\text { external landfill }\end{array}$ & 3 & \\
\hline & $\begin{array}{l}\text { Wastes are previously classified } \\
\text { before its final deposition in an } \\
\text { external landfill }\end{array}$ & 4 & \\
\hline & $\begin{array}{l}\text { Wastes are disposed in } \\
\text { an external landfill }\end{array}$ & 5 & \\
\hline \multirow{4}{*}{$\begin{array}{l}\text { Treatment and } \\
\text { disposal of } \\
\text { radioactive waste } \\
(\mathrm{RW})\end{array}$} & $\begin{array}{l}\text { Wastes are previously } \\
\text { classified, recovered } \\
\text { and reused before its final } \\
\text { deposition in an own landfill }\end{array}$ & 2 & \multirow[t]{4}{*}{3} \\
\hline & $\begin{array}{l}\text { Wastes are previously } \\
\text { classified, recovered and reused } \\
\text { before its final deposition in an } \\
\text { external landfill }\end{array}$ & 3 & \\
\hline & $\begin{array}{l}\text { Wastes are previously classified } \\
\text { before its final deposition in an } \\
\text { external landfill }\end{array}$ & 4 & \\
\hline & $\begin{array}{l}\text { Wastes are disposed in } \\
\text { an external landfill }\end{array}$ & 5 & \\
\hline \multirow{4}{*}{$\begin{array}{l}\text { Treatment and } \\
\text { disposal of biological } \\
\text { waste }(\mathrm{BW})\end{array}$} & $\begin{array}{l}\text { Wastes are previously } \\
\text { classified, recovered } \\
\text { and reused before its final } \\
\text { deposition in an own landfill }\end{array}$ & 2 & \multirow[t]{4}{*}{3} \\
\hline & $\begin{array}{l}\text { Wastes are previously } \\
\text { classified, recovered and reused } \\
\text { before its final deposition in an } \\
\text { external landfill }\end{array}$ & 3 & \\
\hline & $\begin{array}{l}\text { Wastes are previously classified } \\
\text { before its final deposition in an } \\
\text { external landfill }\end{array}$ & 4 & \\
\hline & $\begin{array}{l}\text { Wastes are disposed in an } \\
\text { external landfill }\end{array}$ & 5 & \\
\hline
\end{tabular}


Table 1: Continued

\begin{tabular}{|c|c|c|c|c|}
\hline $\begin{array}{l}\text { Impact } \\
\text { category } \\
\text { (IC) }\end{array}$ & $\begin{array}{l}\text { Environmental aspect } \\
\text { (EA) }\end{array}$ & Assessment criteria (AC) & Value & $\begin{array}{l}\text { Weighting } \\
\text { factor } \\
(\mathrm{WF})\end{array}$ \\
\hline & & Only inside the construction site & 2 & 2 \\
\hline & & $\begin{array}{l}\text { Less than } 1,000.00 \mathrm{~m}^{3} \text {, outside } \\
\text { the construction site }\end{array}$ & 3 & \\
\hline & (S) & $\begin{array}{l}1,000.00-10,000.00 \mathrm{~m}^{3}, \\
\text { outside the construction site }\end{array}$ & 4 & \\
\hline & & $\begin{array}{l}\text { Over } 10,000.00 \mathrm{~m}^{3} \text {, outside } \\
\text { the construction site }\end{array}$ & 5 & \\
\hline & & $\begin{array}{l}\text { Affected area with a slope less } \\
\text { than } 15 \%\end{array}$ & 1 & 3 \\
\hline & Slope land & $\begin{array}{l}\text { Affected area with a slope } \\
\text { between } 15 \% \text { and } 30 \%\end{array}$ & 2 & \\
\hline & modification (SM) & $\begin{array}{l}\text { Affected area with a slope } \\
\text { between } 30 \% \text { and } 60 \%\end{array}$ & 3 & \\
\hline & & $\begin{array}{l}\text { Affected area with a slope } \\
\text { over } 60 \%\end{array}$ & 4 & \\
\hline & Building density (BD) & $\begin{array}{l}\text { The building's area coverage } \\
\text { is less than } 25 \% \text { respect to the } \\
\text { perimeter of the property }\end{array}$ & 2 & 2 \\
\hline & & $\begin{array}{l}\text { The building's area coverage is } \\
\text { between } 25 \% \text { and } 50 \% \text { respect } \\
\text { to the perimeter of the property }\end{array}$ & 3 & \\
\hline & & $\begin{array}{l}\text { The building's area coverage is } \\
\text { between } 50 \% \text { and } 70 \% \text { respect } \\
\text { to the perimeter of the property }\end{array}$ & 4 & \\
\hline & & $\begin{array}{l}\text { The building's area coverage } \\
\text { is over } 70 \% \text { respect to the } \\
\text { perimeter of the property }\end{array}$ & 5 & \\
\hline \multirow{8}{*}{$\begin{array}{l}\text { Flora } \\
\text { and } \\
\text { fauna }\end{array}$} & \multirow{3}{*}{$\begin{array}{l}\text { Wildlife affectation } \\
\text { (WA) }\end{array}$} & No affectation & 1 & 4 \\
\hline & & Affectation & 3 & \\
\hline & & $\begin{array}{l}\text { Affectation of endemic or } \\
\text { protected species }\end{array}$ & 5 & \\
\hline & \multirow{5}{*}{ Deforestation (DF) } & No flora affectation & 1 & 4 \\
\hline & & $\begin{array}{l}\text { Flora affectation without } \\
\text { deforestation }\end{array}$ & 2 & \\
\hline & & $\begin{array}{l}\text { Low deforestation in an area } \\
\text { without forest cover }\end{array}$ & 3 & \\
\hline & & $\begin{array}{l}\text { High deforestation in an area } \\
\text { without forest cover }\end{array}$ & 4 & \\
\hline & & $\begin{array}{l}\text { Deforestation in an area with } \\
\text { forest cover }\end{array}$ & 5 & \\
\hline
\end{tabular}




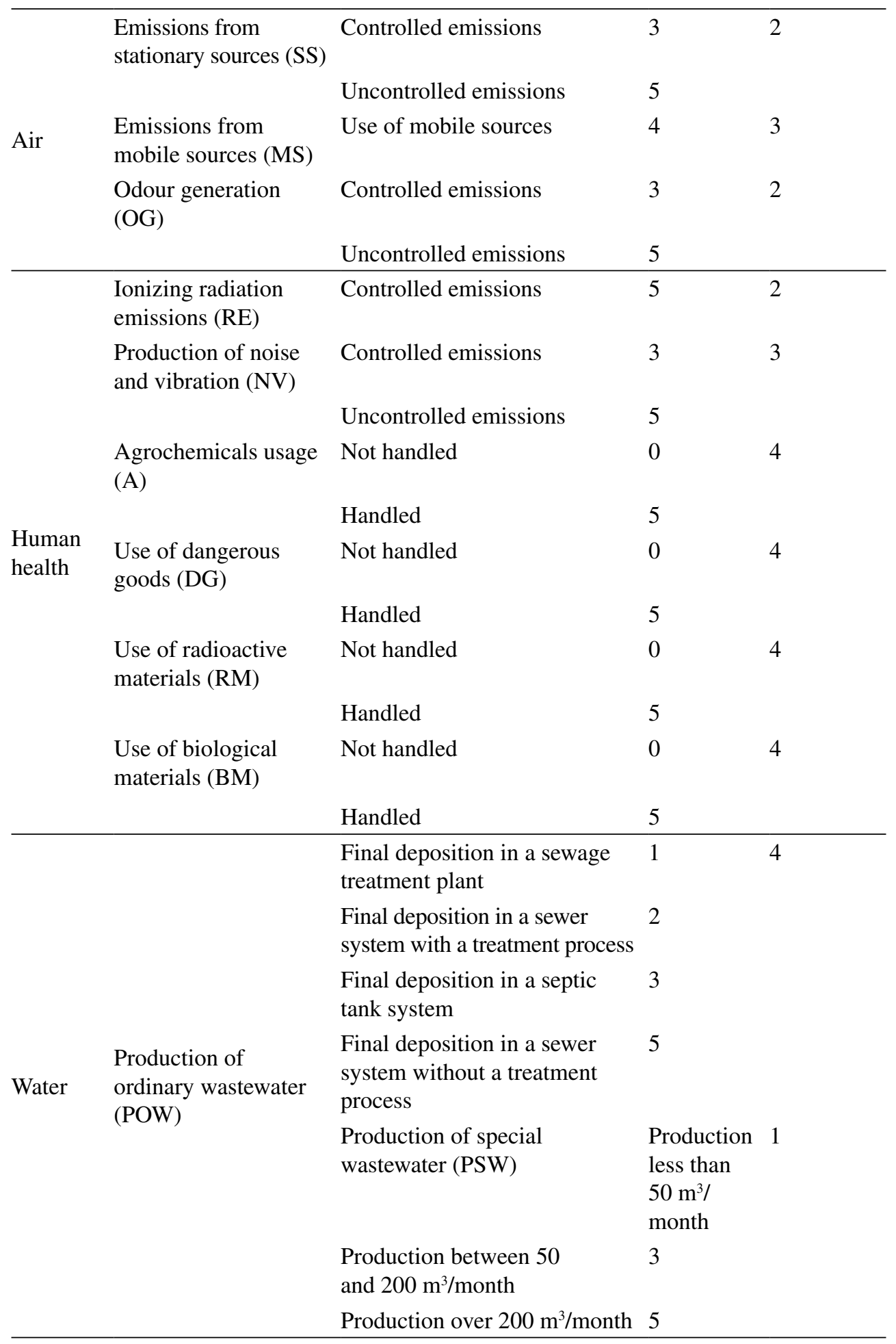


Table 1: Continued

\begin{tabular}{|c|c|c|c|c|}
\hline $\begin{array}{l}\text { Impact } \\
\text { category } \\
\text { (IC) }\end{array}$ & $\begin{array}{l}\text { Environmental aspect } \\
\text { (EA) }\end{array}$ & Assessment criteria (AC) & Value & $\begin{array}{l}\text { Weighting } \\
\text { factor } \\
(\mathrm{WF})\end{array}$ \\
\hline \multirow[t]{18}{*}{$\begin{array}{l}\text { Social- } \\
\text { cultural }\end{array}$} & $\begin{array}{l}\text { Population density } \\
\text { (PD) }\end{array}$ & Less than 50 occupants/Ha & 1 & 3 \\
\hline & & 50-200 occupants/Ha & 3 & \\
\hline & & Over 200 occupants/Ha & 5 & \\
\hline & $\begin{array}{l}\text { Employment } \\
\text { generation (EG) }\end{array}$ & $\begin{array}{l}\text { More than } 100 \text { new } \\
\text { employments }\end{array}$ & 1 & 2 \\
\hline & & $\begin{array}{l}\text { Between } 50 \text { and } 100 \text { new } \\
\text { employments }\end{array}$ & 2 & \\
\hline & & $\begin{array}{l}\text { Between } 25 \text { and } 50 \text { new } \\
\text { employments }\end{array}$ & 3 & \\
\hline & & $\begin{array}{l}\text { Less than } 25 \text { new } \\
\text { employments }\end{array}$ & 4 & \\
\hline & & No new employments & 5 & \\
\hline & People relocation (PR) & No relocating people & 1 & 3 \\
\hline & & Relocating people & 5 & \\
\hline & $\begin{array}{l}\text { Landscape alteration } \\
\text { (LA) }\end{array}$ & $\begin{array}{l}\text { Facilities are constructed in } \\
\text { rural or urban area by using } \\
\text { previous buildings }\end{array}$ & 1 & 3 \\
\hline & & $\begin{array}{l}\text { Facilities are constructed in an } \\
\text { urban area with no alteration } \\
\text { of the landscape }\end{array}$ & 2 & \\
\hline & & $\begin{array}{l}\text { Facilities are constructed in a } \\
\text { rural area with no alteration of } \\
\text { the landscape }\end{array}$ & 3 & \\
\hline & & $\begin{array}{l}\text { Facilities are constructed in an } \\
\text { urban area with alteration of } \\
\text { the landscape }\end{array}$ & 4 & \\
\hline & & $\begin{array}{l}\text { Facilities are constructed in } \\
\text { a rural area with alteration of } \\
\text { the landscape }\end{array}$ & 5 & \\
\hline & $\begin{array}{l}\text { Heritage affectation } \\
\text { (HA) }\end{array}$ & No heritage affectation & 1 & 4 \\
\hline & & $\begin{array}{l}\text { Existing heritage is conserved } \\
\text { and improved }\end{array}$ & 2 & \\
\hline & & Existing heritage is conserved & 3 & \\
\hline
\end{tabular}


Existing heritage is partially

4

affected according to the

national law

Existing heritage is totally

5

affected according to the

national law

Traffic generation

(TG) vehicles

Produces new traffic less
than $25 \%$ of the road network
capacity installed

2.2 Total environmental impact evaluation

The individual environmental impact $\left(\mathrm{IEI}_{\mathrm{EA}}\right)$ for each $\mathrm{EA}$ is calculated according to the formula:

$$
\mathrm{IEI}_{\mathrm{EA}}=\left(\mathrm{AI}_{\mathrm{EA}}\right) \times\left(\mathrm{WF}_{\mathrm{EA}}\right)
$$

wherein $\mathrm{IEI}_{\mathrm{EA}}$ is the individual environmental impact; $\mathrm{AI}_{\mathrm{EA}}$ is the assessment indicator for each $\mathrm{EA}$ (numerical scale) and $\mathrm{WF}_{\mathrm{EA}}$ is the weighting factor assigned to each EA. It is thought that when an EA has an $\mathrm{IEI}_{\mathrm{EA}} \geq 6$ points it becomes an SEA, meaning that such a particular aspect has a high impact onto the IC listed in Table 1.

The TEI for each project $\left(\mathrm{TEI}_{\mathrm{P}}\right)$ is then obtained by using the algorithm

$$
\mathrm{TEI}_{\mathrm{P}}=\sum \mathrm{IEI}_{\mathrm{EA}} \cdot
$$

The SETENA D-1 form allows classification of every project according to TEI values into the following categories: (a) low environmental impact ( $\mathrm{TEI}_{\mathrm{p}} \leq 300$ points), (b) moderate environmental impact $\left(1,000>\mathrm{TEI}_{\mathrm{p}}>300\right.$ points) and (c) high environmental impact (TEI $_{p} \geq 1,000$ points) [25].

\subsection{Data sources}

The data employed to calculate the TEI of each project, during 2012-2015, were obtained from the following sources: 
- Work sessions with architects, civil engineers, mechanic engineers, electric engineers, future-facility users and experts in environmental/social issues

- Public consultation and participation

- Studies around the area of each project: biological environment report, soil and geology evaluation report, archaeological and cultural sites report, hydrological and hydrogeological studies, natural and anthropogenic threats, social-economic and cultural studies, and physical environment report

- Architectonic design, water and energy consumption estimation

- Official documents from Costa Rican Statistical Information Service (INEC), National Institute of Environmental Research (MINAET), Ministry of Public Health and Public Universities Information Centers

- Site inspections

Table 2: Construction areas, footprint constructions, floors and description of the 17 building projects.

\begin{tabular}{|c|c|c|c|c|}
\hline $\begin{array}{l}\text { Project } \\
\text { label }\end{array}$ & $\begin{array}{l}\text { Construction } \\
\text { area }\left(\mathrm{m}^{2}\right)\end{array}$ & $\begin{array}{l}\text { Footprint } \\
\text { construction }\left(\mathrm{m}^{2}\right)\end{array}$ & Floors & Description (planned uses) \\
\hline A & 900.00 & 450.00 & 2 & $\begin{array}{l}\text { Student dormitories with } 18 \text { rooms. } \\
\text { Include bathrooms, kitchens, dining } \\
\text { rooms, meeting rooms }\end{array}$ \\
\hline B & $2,275.00$ & $1,000.00$ & 3 & $\begin{array}{l}\text { Student dormitories with } 39 \text { rooms. } \\
\text { Include bathrooms, kitchens, dining } \\
\text { rooms, meeting rooms }\end{array}$ \\
\hline $\mathrm{C}$ & 803.00 & 803.00 & 1 & $\begin{array}{l}\text { Sport facilities: court for basketball, } \\
\text { volleyball and football. Include toilets, } \\
\text { bathrooms, locker room }\end{array}$ \\
\hline $\mathrm{D}$ & 950.00 & 950.00 & 1 & $\begin{array}{l}\text { Sport facilities: court for basketball, } \\
\text { volleyball and football field. Include } \\
\text { toilets, bathrooms, locker rooms }\end{array}$ \\
\hline $\mathrm{E}$ & $1,250.00$ & 625.00 & 2 & $\begin{array}{l}\text { Student dormitories with } 25 \text { rooms. } \\
\text { Include bathrooms, kitchens, dining } \\
\text { rooms, meeting rooms }\end{array}$ \\
\hline $\mathrm{F}$ & 950.00 & 950.00 & 1 & $\begin{array}{l}\text { Sport facilities: basketball court, volley- } \\
\text { ball and football field. Include toilets, } \\
\text { bathrooms, locker room }\end{array}$ \\
\hline $\mathrm{G}$ & $2,700.00$ & 700.00 & 2 & $\begin{array}{l}\text { Student dormitories with } 48 \text { rooms. } \\
\text { Include bathrooms, kitchens, dining } \\
\text { rooms, meeting rooms. }\end{array}$ \\
\hline $\mathrm{H}$ & 500.00 & 500.00 & 2 & $\begin{array}{l}\text { Areas for administrative matters. } \\
\text { Include bathrooms, toilets, offices, } \\
\text { meeting room }\end{array}$ \\
\hline I & $1,500.00$ & 850.00 & 2 & $\begin{array}{l}\text { Areas for academic, teaching and } \\
\text { administrative matters. Include bath- } \\
\text { rooms, toilets, offices, meeting rooms, } \\
\text { classroom, auditorium }\end{array}$ \\
\hline
\end{tabular}




\begin{tabular}{|c|c|c|c|c|}
\hline $\mathrm{J}$ & $2,500.00$ & $1,000.00$ & 3 & $\begin{array}{l}\text { Areas for academic, teaching and } \\
\text { administrative matters. Include bath- } \\
\text { rooms, toilets, offices, meeting rooms, } \\
\text { classroom, auditorium }\end{array}$ \\
\hline K & $6,000.00$ & $1,200.00$ & 6 & $\begin{array}{l}\text { Areas for academic, teaching and ad- } \\
\text { ministrative matters. Include bathrooms, } \\
\text { toilets, offices, meeting room, classroom, } \\
\text { parking lot, sidewalks, auditorium, } \\
\text { chemical, physical and biological labo- } \\
\text { ratories, chemical products warehouse, } \\
\text { small-scale industrial plant, teaching and } \\
\text { research labs }\end{array}$ \\
\hline $\mathrm{L}$ & $1,115.00$ & 225.00 & 4 & $\begin{array}{l}\text { Areas for academic, teaching and } \\
\text { administrative matters. Include bath- } \\
\text { rooms, toilets, offices, meeting room, } \\
\text { classrooms, chemical and physical } \\
\text { laboratories, dangerous goods ware- } \\
\text { house, small-scale industrial plant, } \\
\text { teaching and research labs }\end{array}$ \\
\hline M & 800.00 & 400.00 & 2 & $\begin{array}{l}\text { Rebuilding areas for classrooms, li- } \\
\text { brary, meeting rooms, computer labs }\end{array}$ \\
\hline $\mathrm{N}$ & $4,000.00$ & $4,000.00$ & 1 & $\begin{array}{l}\text { Include classrooms, library, meeting } \\
\text { rooms, areas for art and dancing, sport } \\
\text { court (basketball, volleyball, soccer), } \\
\text { auditorium }\end{array}$ \\
\hline $\mathrm{O}$ & 400.00 & 200.00 & 2 & $\begin{array}{l}\text { Areas for academic, teaching and } \\
\text { administrative matters. Include bath- } \\
\text { rooms, toilets, offices, meeting room, } \\
\text { classroom, computer labs }\end{array}$ \\
\hline $\mathrm{P}$ & $3,500.00$ & 240.00 & 2 & $\begin{array}{l}\text { Areas for academic, teaching and } \\
\text { administrative matters. Include bath- } \\
\text { rooms, toilets, offices, meeting rooms. }\end{array}$ \\
\hline Q & $2,450.00$ & 700.00 & 4 & $\begin{array}{l}\text { Areas for academic, teaching and } \\
\text { administrative matters. Include bath- } \\
\text { rooms, toilets, offices, meeting rooms, } \\
\text { art and dancing rooms, audiovisual labs }\end{array}$ \\
\hline $\begin{array}{l}\text { Total } \\
(\mathrm{n}=17)\end{array}$ & $32,093.00$ & $14,293.00$ & - & - \\
\hline
\end{tabular}

\section{RESULTS AND DISCUSSION}

Table 2 summarizes the construction areas, footprint constructions, number of floors and planned uses of the 17 building projects. The construction areas lied in the $400.00 \mathrm{~m}^{2}-6,000.00 \mathrm{~m}^{2}$ range. For most of the buildings $(n=12)$ their elevation does not exceed three floors; projects L and Q are four-storey facilities, whereas project $\mathrm{K}$ is the tallest building (six floors) and also spans the largest construction area $\left(6,000.00 \mathrm{~m}^{2}\right)$. The majority $(n=10)$ of these buildings are addressed to be used in administrative and teaching activities. 
However, some facilities were designed to hold special uses; for example, project K contains 23 chemistry-related laboratories (analytical, organic, biochemistry, water and soil quality, atmospheric pollution, pesticides and so on), chemical products/wastes warehouses and a small-scale industrial plant. Project L will bear laboratories and equipment designed to work with radioactive materials. Projects A, B, E and F will be utilized as student dormitories; they have similar structure as well as inputs and outputs, although they vary in the number of rooms. Such dormitory projects are all built in rural areas and have construction areas in the 900.00-2,700.00 $\mathrm{m}^{2}$ range. The total environmental impacts (TEI $_{\mathrm{p}}$ of these dormitory projects are very similar to each other $\left(\mathrm{TEI}_{\mathrm{p}}=133,131,131\right.$ and 139).

Table 3 lists the EA evaluated for all 17 building projects. The EA classified as SEA are indicated with an asterisk symbol (*). For every project, 33 EA were evaluated, in accordance with the AC listed in Table 1. Twenty-two EA (66.67\%) showed IEI $_{\mathrm{EA}}$ outcomes greater than 6 points, and hence they were classified as SEA. Conversely, 11 EA (33.33\%) showed AEI $_{\mathrm{EA}}$ values below 6 points and therefore were classified as non-significant. The following reasons may account for such a behaviour: the EA was not applicable, the construction performances were appropriate, noise-reducing practices were enforced and adequate waste disposal procedures were applied.

Some EA were classified as SEA in all 17 projects, namely treatment and disposal of ordinary wastes, treatment and disposal of debris building, emissions from mobile sources, production of noise and vibration, population density and employment generation. As a result, special attention must be given to these EA.

Table 3: Significant environmental aspects identified for the 17 projects evaluated.

\begin{tabular}{|c|c|c|c|c|c|c|c|c|c|c|c|c|c|c|c|c|c|}
\hline \multirow{2}{*}{$\begin{array}{l}\text { Assessment } \\
\text { criteria }\end{array}$} & \multicolumn{17}{|c|}{ Project } \\
\hline & $\overline{\mathbf{A}}$ & B & $\mathrm{C}$ & D & $\mathbf{E}$ & $\mathbf{F}$ & $\mathbf{G}$ & $\mathbf{H}$ & I & $\mathbf{J}$ & $\mathbf{K}$ & $\mathbf{L}$ & $\mathbf{M}$ & $\mathbf{N}$ & $\mathbf{O}$ & $\mathbf{P}$ & $\mathbf{Q}$ \\
\hline$\overline{\mathrm{WC}}$ & $*$ & $*$ & & & $*$ & & $*$ & $*$ & $*$ & & $*$ & $*$ & $*$ & $*$ & $*$ & & $*$ \\
\hline $\mathrm{EC}$ & $*$ & $*$ & & & $*$ & & $*$ & $*$ & $*$ & & $*$ & $*$ & $*$ & $*$ & & & \\
\hline \multicolumn{18}{|l|}{$\mathrm{FF}$} \\
\hline \multicolumn{18}{|l|}{ SMd } \\
\hline \multicolumn{18}{|l|}{ SR } \\
\hline OW & $*$ & $*$ & $*$ & $*$ & $*$ & $*$ & $*$ & $*$ & $*$ & $*$ & $*$ & $*$ & $*$ & $*$ & $*$ & $*$ & $*$ \\
\hline SW & & & & & & & & & & & $*$ & $*$ & & & & & \\
\hline DB & $*$ & $*$ & $*$ & $*$ & $*$ & $*$ & $*$ & $*$ & $*$ & $*$ & $*$ & $*$ & $*$ & $*$ & $*$ & $*$ & $*$ \\
\hline $\mathrm{CW}$ & & & & & & & & & & & $*$ & $*$ & $*$ & & & & $*$ \\
\hline RW & & & & & & & & & & & & $*$ & & & & & \\
\hline BW & & & & & & & & & & & $*$ & & & & & & \\
\hline $\mathrm{S}$ & & & & & & & & & & & $*$ & $*$ & & & & & \\
\hline SM & & & & & & & & & & & * & & & & & & \\
\hline \multicolumn{18}{|l|}{ BD } \\
\hline \multicolumn{18}{|l|}{ WA } \\
\hline $\mathrm{D}$ & & & & & $*$ & $*$ & $*$ & & & & & & & & & & \\
\hline SS & & & & & & & & & & & $*$ & & & & & & \\
\hline MS & $*$ & $*$ & $*$ & $*$ & $*$ & $*$ & $*$ & $*$ & $*$ & $*$ & $*$ & $*$ & $*$ & $*$ & $*$ & $*$ & $*$ \\
\hline $\mathrm{OG}$ & $*$ & $*$ & $*$ & $*$ & $*$ & $*$ & $*$ & $*$ & $*$ & $*$ & $*$ & $*$ & $*$ & $*$ & $*$ & $*$ & $*$ \\
\hline $\mathrm{RE}$ & & & & & & & & & & & & & & & & & \\
\hline
\end{tabular}




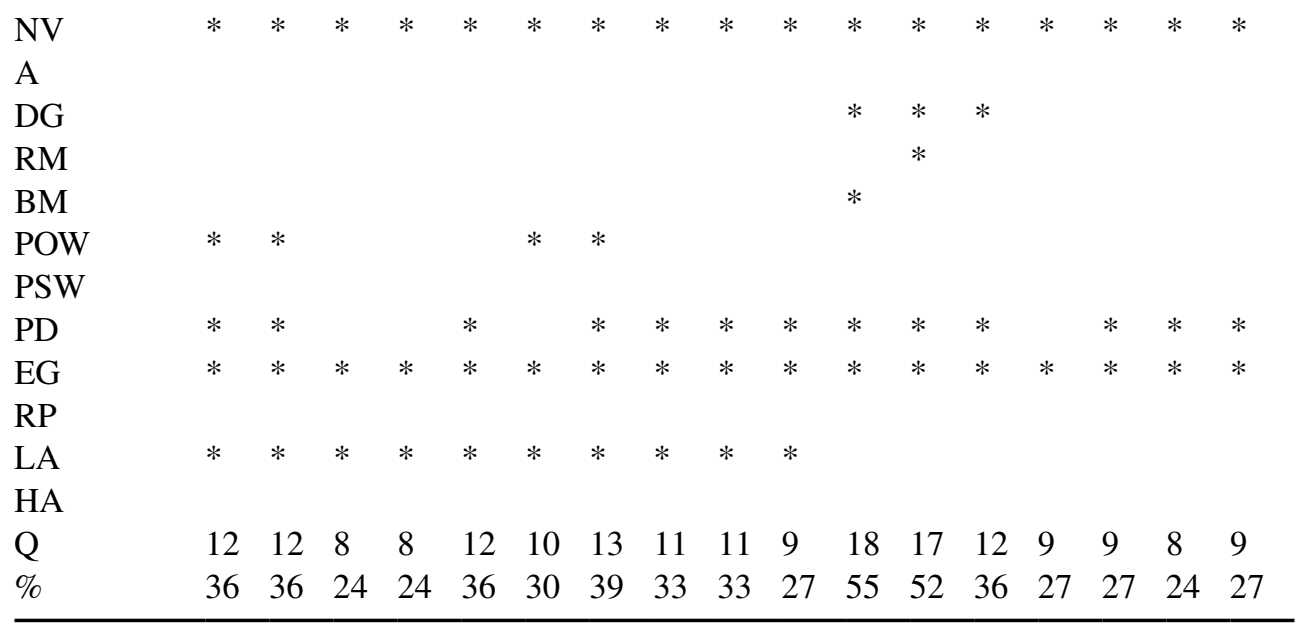

Figure 1 shows the calculated TEI for each project; it must be pointed out that TEI $_{\mathrm{P}}$ values were obtained including all EA, regardless of whether they were significant or not. The majority $(n=10)$ of the projects showed total environmental impact $\left(\mathrm{TEI}_{\mathrm{P}}\right)$ values in the $100-125$ point range, meaning that all of them fall in the low environmental impact category $\left(\mathrm{TEI}_{\mathrm{p}} \leq 300\right.$ points). The internal infrastructure of these two buildings (projects $\mathrm{K}$ and $\mathrm{L}$ ), the future use of these facilities, the environmental inputs (e.g. water need and energy consumption) and outputs (e.g. special wastes produced) during the construction and operation stages provoked account for these two projects to have the highest (values) TEI. Nonetheless, the main difference between these two facilities relies on the fact that project $\mathrm{L}$ will use and store radioactive materials. Also, project $\mathrm{K}$ is bigger ( $\mathrm{m}^{2}$ of construction) than project $\mathrm{L}$, and project $\mathrm{K}$ has a larger amount of laboratories and dangerous goods warehouses. The higher $\mathrm{TEI}_{\mathrm{P}}$ values of projects $\mathrm{K}$ and $\mathrm{L}$ are principally due to the number of their SEA. Table 2 shows 18 and 17 SEA, respectively, for projects K and L. Some EA values of these projects surpassed the 10-point mark.

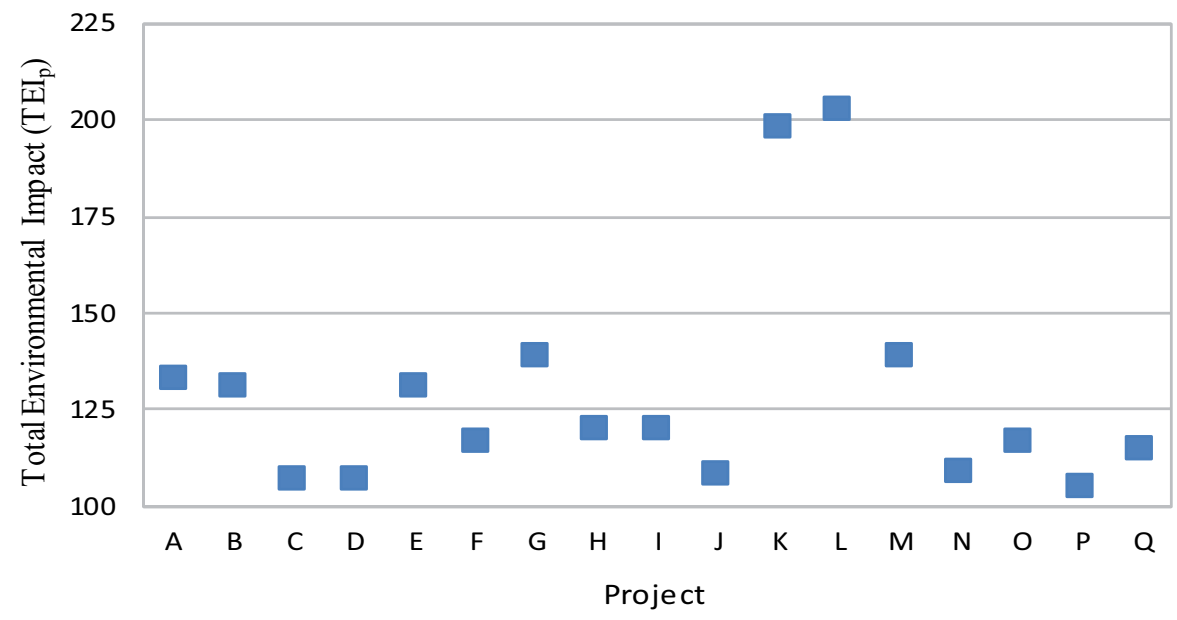

Figure 1: Total environmental impact (TEI p $_{\mathrm{p}}$ of the 17 projects evaluated. 


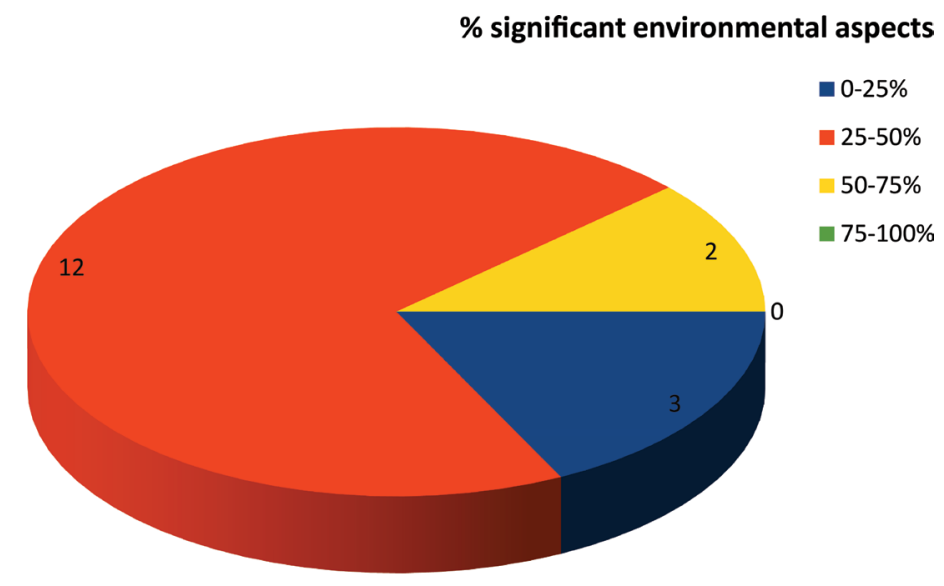

Number of projects

Figure 2: Number of significant environmental aspects associated with each building project.

Figure 2 shows the number of SEA associated with each building project. Projects $\mathrm{C}$, $\mathrm{D}$ and $\mathrm{P}$ have all eight SEA and fall in the 0-25\% SEA interval. Additionally, these three

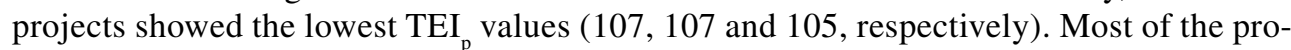
jects $(n=12)$ have $25-50 \%$ of its EA classified as significant. In general, the TEI values of these 12 projects summed up around 109-139 points. Only projects K and L showed SEA values in the 50-75\% range; additionally, these two projects showed the highest TEI. Figure 2 also shows there are no projects with more than 24 SEA (in the 75-100\%), which suggests that during the construction stage all projects will have adequate EA managements so that social/cultural, human and environmental aspects will experience the minimum impact. Both Figs 1 and 2 suggest that as the number of SEA increases so does the TEI.

Figure 3 shows that some EA are significant in all projects, and therefore both the governmental environmental authorities as well as the university staff must exert an adequate management of these SEA during the construction stage: treatment and disposal of ordinary wastes (OW), treatment and disposal of debris building (DB), emission from mobile sources (MS), production of noise and vibration (NV), employment generation (EG) and traffic generation vehicles (TG). These SEAs should be incorporated into a general evaluation protocol for assessing every single construction project to be developed at any campus of Universidad Nacional. In addition, some specific EA (for instance, RW, $\mathrm{BW}, \mathrm{BM}$ ) would require additional expertise for their assessment, and hence they must be included into the general evaluation protocol as optional subjects whenever it would be necessary.

It is important to point out that the D-1 form does not have the same number of assessment indicators for all EA, and neither have the same weighing scale; for instance, WC has three $\mathrm{AC}$ (1, 3 and 5) evaluation values, whereas SR shows five AC values (1, 2, 3, 4 and 5). As a result, the D-1 form does not allow to determine which EA is more relevant (since they are not assessed equally), and therefore such an evaluation tool needs to be improved in order to provide better assessment outcomes. 


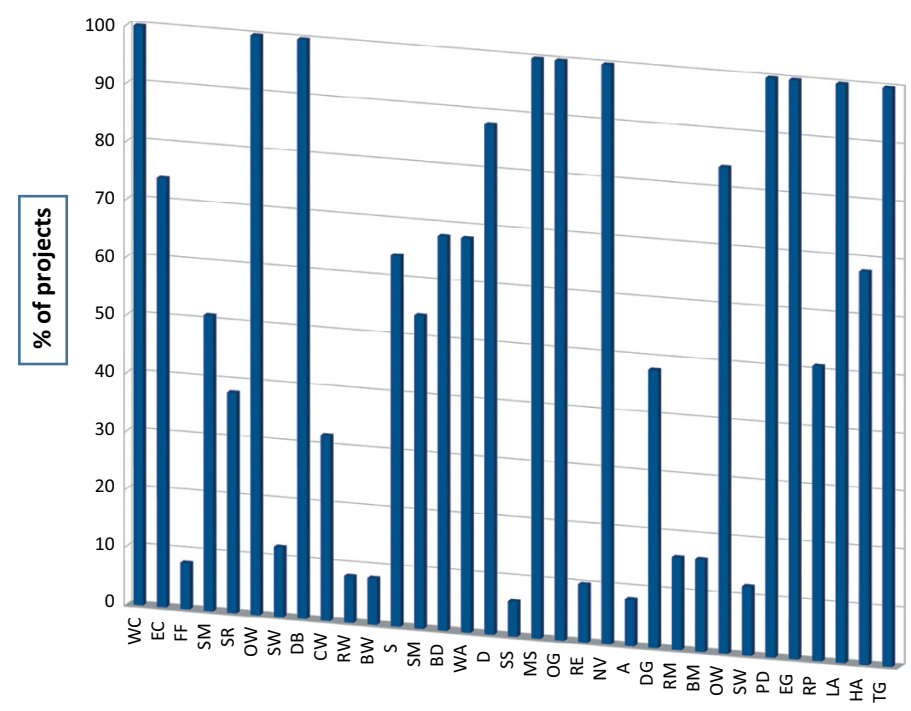

Significant environmental aspects

Figure 3: Percentage distribution of the significant environmental aspects in the 17 projects evaluated.

\section{CONCLUSION}

The Environmental National Technical Secretariat of Costa Rica (SETENA) employs an assessment tool, called the D-1 form, to preliminarily estimate the potential environmental impact that a building project may have on the surroundings. Seventeen construction projects to be developed at various campuses of Universidad Nacional, Costa Rica, during 20152018, were assessed employing the D-1 form. The assessment showed that all these building projects may be rated as 'low environmental impact'.

The construction areas of the 17 projects evaluated vary from $400.00 \mathrm{~m}^{2}$ to $6,000.00 \mathrm{~m}^{2}$. The majority $(n=10)$ of the buildings are going to be used in administrative activities as well as classrooms. The TEI values of the 17 projects evaluated are in the 105-203 point range. Projects $\mathrm{K}$ and $\mathrm{L}$ show the higher $\mathrm{TEI}_{\mathrm{p}}$ values due to their special requirements to manage chemical and biological substances, as well as radioactive materials.

Thirty-three EA were evaluated, and 22 of them were classified as SEA, since their individual values were greater or equal to six points. Six SEA were common to all projects: treatment and disposal of ordinary wastes, treatment and disposal of debris building, emissions from mobile sources, production of noise and vibration, population density and employment generation, and hence they must be integrated into one general evaluation protocol for assessing every single construction project to be developed.

A $33 \%$ of the EA evaluated were considered not significant. This means that they have a low environmental impact on the eight environmental sectors evaluated (natural resources, soil, wildlife, flora, air, human health, water and socio-cultural) during this investigation.

Most of the projects $(n=12)$ have between $25 \%$ and $50 \%$ of its aspects classified as SEA. The TEI for these 12 projects is very close to each other. Only two projects ( $\mathrm{K}$ and $\mathrm{L}$ ) have more than 16 SEA (percentage range between $75 \%$ and $100 \%$ ). These two projects show the 
higher TEI. It could be concluded that there is a direct relationship between the quantity of SEA and final value for TEI .

Despite its usefulness, the SETENA D-1 form needs to be improved in order to provide better assessment results. Some EA of the D-1 form have unequal number of AC and also different value scales. As a consequence, the D-1 form does not equally evaluate all EA, and therefore it does not allow establishing which EA are more relevant.

\section{REFERENCES}

[1] Judith, P. \& Barry, S., A framework for environmental sustainability assessment and assurance. Handbook of Environmental Impact Assessment, 2, pp. 12-31, 1999. ISBN: 978-0-632-04773-4.

[2] Selvakumar, S. \& Jeykumar, R.K.C., Environmental impact assessment for building construction projects. International Journal of Computational Sciences and Information Technology 1 1(1), pp. 29-40, 2015.

[3] Amit, B.D. \& Ipshita, S., Environmental Impact Assessment (EIA) and construction. International Research Journal of Environment Sciences, 3(1), pp. 58-61, 2014.

[4] Arquiaga, M.C., Canter, L.W. \& Nelson, D.I., Risk assessment principles in environmental impact studies. Environmental Professionals, 14, pp. 204-219, 1992.

[5] Edoka, A.I., Richard, A.J., Bamidele, O.A. \& Abduiquadri, B.A., An assessment of environmental impacts of building construction projects. Civil and Environmental Research, 3(1), pp. 93-104, 2013. ISSN 2222-1719 (Paper) ISSN 2222-2863 (Online).

[6] Howard, N., Data for Sustainable Construction, Center for Sustainable Construction, UK available at http://projects.bre.co.uk/sustainable/SusConstructionData.pdf, 2000 (accessed September 2016).

[7] Howard, N., Data for Sustainable Construction, Center for Sustainable Construction, available at http://projects.bre.co.uk/sustainable/SusConstructionData.pdf (accessed 10 October 2016).

[8] Environment Agency. Scoping Guidelines on the Environmental Impact Assessment (EIA) of Projects, Rotherham, UK, available at https://www.gov.uk/government/ uploads/system/uploads/attachment_data/file/297112/geho0112bwak-e-e.pdf (accessed 15 August 2016).

[9] Armitage, P.D. \& Pardo, I., Impact assessment of regulation at the reach level using macroinvertebrate information mesohabitats. ResearchandManagement, 10, pp.147-158, 1995. DOI: $10.1002 / \mathrm{rrr} 3450100210$.

[10] Construction Industry Research and Information Association, Sustainable Urban Drainage Systems-Best Practice Guide, C523, CIRIA: London, UK, 2001.

[11] Environment Agency. Working at Construction or Demolition Sites. Pollution Prevention Guidelines No.6. Environment Agency: Bristol, UK, 1998.

[12] International Organization of Standardization, Environmental Management - Life Cycle Assessment - Principles and Framework, EN ISO 14040, International Organization of Standardization: Geneva, 1997.

[13] International Organization of Standardization, Environmental Management - Life Cycle Assessment - Goal and Scope Definition and Inventory Analysis, ISO 14041, International Organization of Standardization: Geneva, 1998.

[14] Trinius, W., Environmental Assessment in Building and Construction: Goal and Scope Definition as Key to Methodology Choices. Doctoral Thesis. Kungliga Tekniska Hogskolan, Stockholm, 1999. 
[15] Administrative Staff College of India, Environmental Impact Assessment Guidance Manual for Building, Construction, Townships and Area Development Projects. Ministry of Environment and Forest. Government of India: New Delhi, 2010.

[16] Gangollells, M., Casals, M., Gassó, S., Forcada, N., Roca, X. \& Fuertes, A., Assessing concerns of interested parties when predicting the significance of environmental impacts related to the construction process of residential buildings. Building and Environment, 46, pp. 1023-1037, 2011. DOI: 10.1016/j.buildenv.2010.11.004.

[17] Li, X., Zhu, Y. \& Zhang, Z., An LCA-based environmental impact assessment model for construction processes. Building and the Environment, 45, pp. 766-775, 2010. DOI: 10.1016/j.buildenv.2009.08.010.

[18] Shen, L.Y., Lu, W.S., Yao, H. \& Wu, D.H., A computer-based scoring method for measuring the environmental performance of construction activities. Automation in Construction, 14, pp. 97-309, 2005. DOI: 10.1016/j.autcon.2004.08.017.

[19] Levin, H., Systematic Evaluation and Assessment of Building Environmental Performance (SEABEP). Paper for presentation Buildings and Environment, Paris, 9-12 June 1997.

[20] Chen, Z., Li, H. \& Wong, C.T.C., Environmental management of urban construction projects in China. Journal of Construction Engineering and Management, 126, pp. 320-324, 2000. DOI: 10.1061/(ASCE)0733-9364(2000)126:4(320).

[21] Lam, P.T.I., Chan, E.H.W., Chau, C.K., Poon, C.S. \& Chun, K.P., 'Environmental management system vs green specifications: How do they complement each other in the construction industry?'. Journal of Environmental Management, 92, pp. 788-795, 2011. DOI: 10.1016/j.jenvman.2010.10.030.

[22] Trinius, W., Environment Assessment - Implementation in the Building Sector, Licentiate of Engineering Thesis: Stockholm, 1998.

[23] Sanchez, E.T. \& Enriquez, S., Draft: A Comparative Analysis of Environmental Impact Analysis Systems in Latin America, 2007, available at http://www.ifc.org/wps/ $\mathrm{wcm} / \mathrm{connect} / \mathrm{c} 688 \mathrm{c} 7004 \mathrm{c08ac00ae87be79803d5464/2 \_ EIA+in+LAC+IAIA+Seoul.}$ pdf?MOD=AJPERES, 2007 (accessed September 2016).

[24] Netherlands Commission for Environmental Assessment. Costa Rica: History of EIA. 2011, available at http://www.eia.nl/en/countries/ca/costa+rica/ (accessed September 2016).

[25] Ministerio de Ambiente y Energía. Secretaría Técnica Nacional Ambiental. Documento de Evaluación Ambiental D-1.2005, availiable at https://www.setena.go.cr/formulariosd1-d2/ (accessed September 2016). 